\title{
METODE ANALYTIC NETWORK PROCESS (ANP) UNTUK MENGANALISIS FAKTOR BELUM DITERAPKANNYA MUNICIPAL ISLAMIC BONDS PADA DAERAH BERPOTENSI SUKUK DI INDONESIA
}

\author{
Erma Sri Hastuti \\ Bedjo Santoso \\ Universitas Islam Sultan Agung Semarang \\ ermahastuti22@gmail.com
}

\begin{abstract}
This study aims to analyze what factors affect has not been applied municipal islamic bonds in a potentially sukuk region in Indonesia. Previous research already exists that discusses which areas have the potential to publish municipal Islamic bonds but until now no region has published municipal islamic bonds. Whereas municipal Islamic bonds can cover the budget deficit of regional income and can finance the development of regional infrastructure so that no need debt. Therefore, the authors do research what factors are the cause by using the method of analytic network process to obtain the priority scale of the causal factor has not been applied municipal islamic bonds in the area of potentially sukuk in Indonesia. From this research, it is found that there are two main problem that is internal and external problem. In the internal problem which becomes the main factor is Human Resources being in external problem which become the main factor is government regulation.
\end{abstract}

Keywords: Analytic Network Process, Sukuk, Municipal Islamic Bonds

\section{PENDAHULUAN}

Di Indonesia sukuk terus berkembang sejak keluarnya fatwa MUI tentang obligasi syariah. Sukuk di Indonesia diawali dengan terbitnya corporate sukuk ditahun 2002. Kemudian diikuti pemerintah yang mengeluarkan Sukuk Negara (sovereign sukuk) di tahun 2008 untuk pembiayaan yang diprioritaskan melalui Anggaran Pendapatan dan Belanja Negara (APBN), bersamaan dengan diterbitkannya Undangundang No.19 Tahun 2008 tentang Surat Berharga Syariah Negara (SBSN) yang ditetapkan pada bulan April 2008. Implikasi diterbitkannya undang-undang tersebut memberikan peluang kepada pemerintah daerah untuk menggunakan sukuk sebagai alternatif pembiayaan berbagai proyek di daerah, setelah sebelumnya ditahun 2005 telah terbit Peraturan Pemerintah (PP) No 54 tahun 2005 tentang pinjaman daerah.

Sukuk daerah atau Municipal Islamic Bonds adalah surat berharga syariah negara yang diterbitkan oleh pemerintah daerah atau lembaga pemerintah yang digunakan untuk membiayai pembangunan di daerah. Dengan menerbitkan Sukuk, pemerintah daerah dapat membantu anggaran daerah yang mengalami defisit serta melakukan percepatan pembangunan proyek infrastruktur berupa jalan raya, bandara, pelabuhan, jembatan, sekolah, rumah sakit, dan sebagainya. Sehingga sukuk memiliki potensi yang sangat besar 
Tabel 1 Gambaran Umum Postur APBD 2012-2014

\begin{tabular}{lccc}
\hline & APBD 2012 & APBD 2013 & APBD 2014 \\
\hline Komposisi PAD & $20 \%$ & $20.65 \%$ & $22.67 \%$ \\
Dana Perimbangan & $66 \%$ & $63.43 \%$ & $60.45 \%$ \\
Pendapatan lainnya & $14 \%$ & $16.02 \%$ & $16.88 \%$ \\
Total Pendapatan & Rp 577,079.88 & Rp 682,341.96 & Rp 796,864.84 \\
Total Belanja & Rp 617,542.17 & Rp 736,559.74 & Rp 855,266.45 \\
Surplus/defisit & Rp - 40,462.29 & Rp - 54,217.78 & Rp - 58,401.61 \\
\hline
\end{tabular}

sebagai alternatif sumber pendanaan pembangunan daerah.

Percepatan pembangunan daerah membutuhkan investasi untuk proyek jangka panjang. Salah satunya adalah dengan menggunakan sukuk untuk pembangunan infrastruktur. Sebenarnya pembangunan suatu daerah diperoleh dari dua sumber yaitu: Anggaran Pendapatan dan Belanja Negara (APBN) dan Anggaran Pendapatan dan Belanja Daerah (APBD). Namun ada kendala yang berasal dari pendanaan daerah yaitu APBD yang selalu defisit. Data dari tahun 2012 hingga tahun 2014, secara makro defisit APBD terus meningkat. Hal ini mengindikasikan bahwa masih terjadi ketergantungan daerah terhadap pusat yang belum sesuai dengan cita-cita otonomi daerah (Hamzah, Maulana, 2015).

Diantara manfaat sukuk daerah adalah membantu percepatan program pembangunan daerah dengan peran serta masyarakat. Sehingga alangkah baiknya jika objek pembiayaan sukuk daerah lebih ditekankan kepada proyek publik yang bersifat profit oriented namun dapat memberikan implikasi pada masyarakat luas, salah satunya adalah dengan pembangunan infrastruktur. Hal ini didukung oleh masyarakat Indonesia yang mayoritas penduduknya adalah muslim.

Menurut hitungan rasional, instrumen sukuk lebih menguntungkan daripada obligasi konvensional, seperti nilai return yang lebih menjanjikan dan sistem kepemilikannya. Penelitian sebelumnya sudah ada yang menyebutkan bahwa ada daerah yang berpotensi untuk menerbitkan sukuk seperti Jawa Barat, Jawa Tengah, Jawa Timur, DKI Jakarta, Jambi, Kepulauan Riau dan Sumatra Barat, namun sampai sekarang daerah tersebut belum menerbitkan sukuk. Pasti ada penyebab yang membuat daerah tersebut belum mengeluarkan sukuk. Sehingga penelitian ini berusaha untuk menjawab hal tersebut.

\section{Rumusan Masalah}

Berdasarkan gambaran latar belakang diatas, maka dapat disusun rumusan masalah yang dapat digunakan sebagai petunjuk melaksanakan penelitian. Rumusan masalah tersebut adalah apa saja yang menjadi faktor belum diterapkannya municipal islamic bonds pada daerah berpotensi sukuk di Indonesia.

\section{Tujuan Penelitian}

Penelitian ini dimaksudkan untuk menganalisis permasalahan faktor-faktor apa saja yang mempengaruhi belum diterapkannya Municipal Islamic Bonds pada daerah berpotensi sukuk di Indonesia serta apa yang menjadi faktor utama (yang paling berpengaruh).

\section{KAJIAN PUSTAKA \\ Pengertian Sukuk}

Menurut fatwa Majlis Ulama Indonesia No 32/DSN-MUI/IX/2002 sukuk adalah suatu 
surat berharga jangka panjang berdasarkan prinsip syariah yang dikeluarkan emiten kepada pemegang obligasi syariah yang mewajibkan emiten untuk membayar pendapatan kepada pemegang obligasi syariah berupa bagi hasil/margin/fee, serta membayar kembali dana obligasi pada saat jatuh tempo.

Berdasarkan Standar Syariah The Accounting and Auditing Organization for Islamic Financial Institutions (AAOIFI) No.17 tentang sukuk investasi, sukuk didefinisikan sebagai sertifikat bernilai sama yang merupakan bukti atas bagian kepemilikan yang tak terbagi terhadap suatu aset, hak manfaat, dan jasa-jasa, atau atas kepemilikan suatu proyek atau kegiatan investasi tertentu.

\section{Pengertian Obligasi Daerah}

Obligasi daerah merupakan obligasi milik daerah yang ditawarkan kepada masyarakat melalui pasar modal. Obligasi daerah dapat digunakan untuk membiayai infrastruktur daerah dengan tetap meminimalkan risiko yang ada. Berikut dasar-dasar hukum yang melandasi obligasi daerah (1) UndangUndang Nomor 8 Tahun 1995 tentang Pasar Modal; (2) Undang-Undang Nomor 33 Tahun 2004 tentang Perimbangan Keuangan Antara Pemerintah Pusat dan Pemerintah Daerah; (3) UU Surat Berharga Syariah Nasional (SBSN) yang baru saja disahkan DPR pada 10 April 2008; (4) Peraturan Menteri Keuangan Nomor 111/ PMK.07/2012 tentang Tata Cara Penerbitan Dan Pertanggungjawaban Obligasi Daerah; (4) Paket Peraturan Otoritas Jasa Keuangan Terkait Penawaran Umum Obligasi Daerah.

Pemerintah Daerah dapat menerbitkan Obligasi Daerah sepanjang memenuhi persyaratan pinjaman diantaranya adalah (1) Mendapat persetujuan DPRD (2) Audit terakhir Laporan Keuangan Pemerintah Daerah mendapat opini Wajar Dengan Pengecualian (WDP) atau Wajar Tanpa Pengecualian. (3) Jumlah sisa pinjaman daerah + jumlah pinjaman yang akan ditarik tidak melebihi $75 \%$ dari jumlah penerimaan umum APBD tahun Sebelumnya. (4) Memenuhi rasio kemampuan daerah untuk mengembalikan pinjaman (DSCR) yang ditetapkan oleh pemerintan(firmansyah, deki, 2016).

\section{Perbedaan Esensial Kebijakan Fiskal Konvensional Dan Islami}

Menurut Candra Natadipurba (2015) Kebijakan fiskal adalah kebijakan mengenai sistem keuangan yang dapat digunakan pemerintah untuk mempengaruhi perekonomian secara cepat sehingga permasalahan ekonomi dapat diselesaikan, setidaknya untuk sementara. Sedangkan dalam Islam kebijakan fiskal adalah kebijakan yang berhubungan dengan sistem pendapatan dan pengeluaran negara yang bertujuan pada kesejahteraan masyarakat luas. Kebijakan yang harus lebih mengutamakan kepentingan masyarakat luas dibanding kepentingan aparatur pemerintah itu sendiri. Aparatur pemerintah negara adalah pegawai negara yang seharusnya menjadi teladan di masyarakat, baik profesional dan moral sebab pengelolaan negara berada pada mereka.

\section{Kebijakan Fiskal dan Distribusi Pendapatan}

Untuk lebih efisien dalam pengelolaan belanja hendaknya pemerintah melibatkan rakyat dalam menyediakan barang dan jasa. Misalnya mengenai pengadaan mobil dinas dan rumah dinas. Dibandingkan membuat rumah dinas sendiri dan membeli mobil dinas sendiri, sebaiknya pemerintah menyewa rumah dinas dan mobil dinas dari masyarakat. Keuntungannya pemerintah mendapatkan rumah dinas dan mobil dinas yang baru dari tahun ke tahun dan masyarakat mendapatkan pendapatan dari pemerintah. Hendaknya perlu diatur agar pihak yang menyewakan rumah dan mobil dinas tersebar dan tidak dimonopoli kalangan tertentu saja (Natadipurba, candra, 2015) 


\section{Utang dalam Perspektif Islam}

Utang dapat dikategorikan pada al-mal al-Hukmi: "sesuatu yang dimiliki pemberi hutang, sementara harta itu berada pada orang yang berhutang." Sehingga utang negara adalah milik rakyat dan digunakan untuk keperluan rakyat (Huda et al., 2012; Az- Zain 1995).

Jika Pemerintah berutang seharusnya memperhatikan kemaslahatan umat karena pemerintah merupakan pelaksana wewenag negara yang menjadi wakil rakyat. Masih ada alternatif lain yang bisa dilakukan negara untuk menutupi defisit anggaran seperti mewajibkan rakyatnya untuk membayar zakat atau menerbitkan sukuk untuk pembiayaan infrastruktur.

Menghindari utang dan beralih untuk menerbitkan sukuk adalah solusi yang bisa dipilih negara. Menerbitkan sukuk dapat memberi kesempatan masyarakat untuk berpartisipasi dalam pembangunan nasional. Karena jika menerbitkan sukuk dan hanya memperbolehkan masyarakat sebagai investor tanpa adanya investor asing maka dapat dikatakan bahwa masyarakat telah berpartisipasi dalam pembangunan.

\section{Penelitian Terdahulu}

Berdasarkan penelitian sebelumnya, ada beberapa darah yang berpotensi untuk menerbitkan sukuk daerah. Seperti penelitian Hamzah Maulana (2015) memetakan daerah berpotensi sukuk di Indonesia dilakukan dengan empat tahapan yaitu menentukan nilai IKK (Indeks Kemampuan Keuangan) melalui analisa elastisitas, share dan growth, menentukan nilai IMP (Indeks Maksimal Pinjaman) dan berdasarkan opini BPR terhadap LKPD (Laporan Keuangan Pemerintah Daerah) hasil dari ketiga analisis tersebut dimasukkan dalam matriks yang dihitung dengan metode Bayes untuk menentukan nilai IKP(Indeks Kemampuan Penerbitan Sukuk). Dari penelitiannya diperoleh bahwa ada lima daerah yang berpotensi sukuk yaitu Jawa Barat, DKI Jakarta, Jawa Timur,
Jawa Tengah dan Kepulauan Riau.

Walidi (2009) memetakan tentang peta penawaran dan permintaan atas penerbitan sukuk daerah ditinjau dari PAD (Pendapatan AsliDaerah)daerah setempatdengan sampel 33 propinsi di Indonesia dari tahun 2004 dan 2005. Melalui analisis share, growth dan elastisitas serta melakukan analisis DSCR (Debt Service Coverage Ratio) dan besaran batasan pinjaman merujuk PP No.54 Tahun 2005. Sedangkan dari sisi permintaan sukuk propinsi digunakan parameter jumlah penduduk muslim, jumlah dana likuid dan jumlah keluarga sejahtera untuk masing - masing propinsi. Hasil penelitian tersebut menemukan bahwa ada 7 propinsi berpotensi sukuk yaitu Jawa Barat, Jawa Tengah, Jawa Timur, DKI Jakarta, jambi dan Sumatra Barat.

Muslim Sarip (2010) dengan metode yang sama tetapi hanya lingkup Jawa Barat sampel data dari tahun 2007-2008. Hasilnya ada delapan kota/kabupaten yang berpotensi menerbitkan sukuk yaitu Kota Bandung, Kota Bekasi, Kobupaten Sukabumi, Kabupaten Cirebon, Kabupaten Garut, Kabupaten Bandung, Kabupaten Bogor Dan Kabupaten Bekasi.

Namun demikian, peneliti terdahulu tidak ada (sedikit) yang membahas apa saja masalah yang menjadi penyebab mengapa municipal islamic bonds tidak diimplementasikan di Daerah. Oleh karena itu, penelitian ini berusaha menjawab isu tersebut.

\section{METODE PENELITIAN}

Metode pengumpulan data ketika mengelaboret model dalam penelitian ini adalah kuantitatif - kualitatif. Metode yang digunakan adalah metode Analytic Network Process (ANP) untuk mengidentifikasi faktor belum diterapkannya Municipal Islamic Bonds pada daerah berpotensi sukuk di Indonesia.

Pendekatan ANP digunakan untuk mencari faktor-faktor utama yang memiliki pengaruh paling dominan serta menentukan 
urutan prioritasnya, sehingga dapat digunakan untuk mencari prioritas alternatif solusi dan strategi kebijakan yang tepat dan akhirnya dapat memberikan masukan rekomendasi - rekomendasi yang tepat dan optimal untuk menjawab permasalahan dan tujuan penelitian (Tanjung,Hendri dan Devi, Abrista, 2013)

\section{Sumber Data \\ Data Primer}

Penelitian ini menggunakan data primer. Data primer pada penelitian ini diperoleh dari hasil wawancara langsung kepada responden yang dapat memberikan informasi, fakta dan gambaran peristiwa yang diinginkan dalam penelitian (Lofland,1984 dikutip Ibrahim, 2015).

\section{Data Sekunder}

Data sekunder diperoleh dari pihak kedua berupa dokumen, baik dalam bentuk tertulis (disertasi, tesis, jurnal, buku, artikel di internet) maupun foto (Ibrahim, 2015). Data sekunder digunakan untuk kajian literatur dalam menguatkan teori dan untuk mengetahui penelitian terdahulu yang berkaitan dengan penelitian yang sedang diteliti.

\section{Metode Pengumpulan Data}

Metode pengumpulan data yang digunakan dalam penelitian ini yaitu:

\section{Pengamatan/ observasi}

Observasi deskriptif menjadi acuan dalam penelitian ini karena pada awalnya belum menentukan masalah utama untuk diteliti, melainkan masih sebatas mengumpulkan data, fakta dan informasi umum, secara menyeluruh mengenai apa yang didengar, dilihat dan diamati di lapangan.

\section{Wawancara Tak Terstrukturl in-depth interview}

Wawancara Tak Terstruktur atau in-depth interview menurut Kaelan (2012) dikutip Ibrahim (2015) adalah proses pengumpulan data yang tidak menggunakan wawancara yang sistematis, terstruktur dan lengkap. Pedoman atau panduan wawancara hanya berupa garis besar dari permasalahan yang akan ditanyakan dalam wawancara. Pedoman wawancara berfungsi untuk mengawal proses wawancara agar tidak menyimpang dari topik yang sedang diteliti. Sehingga peneliti dapat memperoleh jawaban yang diinginkan.

Responden dalam penelitian ini adalah mereka yang ahli (pakar) terhadap masalah yang sedang diteliti, mereka praktisi yang kesehariannya berkecimpung dalam urusan masalah yang akan diteliti dan mereka para akademisi yang pada umumnya paham akan teori dari masalah yang diteliti (Tanjung, Hendri dan Devi, Abrista, 2013).

Responden penelitian ini adalah Pak Irfan yang merupakan aktivis keuangan syariah, DRE merupakan praktisi sukuk di Bahrain, DRH sebagai akademisi dan Z sebagai Ph.D student yang sedang meneliti sukuk.

\section{Dokumentasi}

Teknik pengumpulan data dokumentasi merupakan sebuah informasi, fakta dan data yang diinginkan dalam penelitian berupa catatan, foto, rekaman, video dan lain sebagainya. Metode ini digunakan untuk mendukung hasil temuan penelitian.

\section{Metode Kepustakaan}

Teknik pengumpulan data dengan membaca buku perpustakaan atau literatur yang digunakan untuk mendukung dalam proses penelitian. Karena dalam penelitian ini tetap membutuhkan panduan yang dapat mengembangkan data yang telah dikumpulkan.

\section{Teknis Analisis}

Seluruh hasil data yang dikumpulkan ataupun dihimpun dalam penelitian ini akan dianalisa secara kualitatif. Berikut langkah dari metode Analytic Network Process (ANP) yang harus ditempuh. Yaitu: 
Membuat model yang disusun berdasarkan dari hasil kajian pustaka dan memberikan pertanyaan kepada para ahli dan praktisi yang memahami dan menguasai masalah yang diteliti serta melakukan wawancara mendalam untuk menilai informasi yang lebih lengkap untuk mendapatkan permasalahan yang sebenarnya secara komprehensif.

Dekomposisi untuk mengidentifikasi serta menganalisa sehingga dapat menstruktur kompleksitas masalah berdasarkan hasil wawancara ke dalam jaringan ANP.

Menyususn atau membuat kuesioner perbandingan (pair wise comparison) berdasarkan pada jaringan ANP yang sudah dibuat. Melakukan wawancara dengan meminta pakar atau praktisi untuk mengisi kuesioner perbandingan (pair wise comparison).

Memproses data dengan memasukkan hasil pengisian kuesioner perbandingan ke dalam software ANP yaitu super decisions.

Menganalisa hasil dan mengajukan rekomendasi strategi.

\section{HASIL DAN PEMBAHASAN Identifikasi Masalah}

Artikel aku cinta keuangan syariah tahun 2016 menyebutkan bahwa Direktur Pasar Modal Syariah OJK Fadilah Kartikasari mengatakan ada beberapa faktor yang menyebabkan pemerintah daerah masih belum menerbitkan sukuk daerah. Salah satunya adalah pemerintah pusat tidak menjamin obligasi daerah.

Sedangkan Direktur Pembiayaan Syariah Direktorat Jenderal Pengelolaan Pembiayaan dan Risiko Kementerian Keuangan Suminto mengatakan bahwa adanya keterkaitan antara kebijakan fiskal dengan penerbitan obligasi daerah. Hal ini dimaksudkan agar daerah yang mengeluarkan obligasi daerah memang mampu untuk membayar fee. Selain itu keamanan investor saat berinvestasi di sukuk daerah pun harus dijamin. Supaya saat terjadi pergantian pemerintahan, fee sukuk tetap bisa dibayarkan. Investor tentu tidak mau terkena risiko politik. Investor tidak mau membeli surat berharga kalau tidak ada kepastian saat pergantian rezim lalu sukuk tidak diakui.

Reza Sadat Shahmeini, Kepala Perwakilan Bursa Efek Indonesia (BEI) Padang menyebutkan bahwa syarat untuk menerbitkan obligasi daerah yaitu mendapatkan persetujuan DPRD, audit terakhir laporan keuangan pemerintah daerah mendapat opini WDP atau WTP, ketentuan jumlah pinjaman daerah plus jumlah pinjaman yang akan ditarik tidak melebihi $75 \%$ dari jumlah penerimaan umum APBD tahun sebelumnya, dan memenuhi rasio kemampuan keuangan daerah untuk mengembalikan pinjaman (DSCR) yang ditetapkan oleh pemerintah (artikel market. bisnis.com, 2016).

Deputi Komisioner Pengawas Pasar Modal III Otoritas Jasa Keuangan (OJK), M. Noor Rachman menjelaskan bahwa sukuk obligasi pemerintah daerah tidak dijamin negara, sehingga harus ikut persyaratan kelaikan yang ada. "Setiap penerbitan sukuk pada prinsipnya harus terbuka, baik aset maupun utang dalam dokumen prospektus, laporan keuangan, opini legal, peringkat, akutansi sukuk juga menggunakan Pernyataan Standar Akutansi Keuangan (PSAK) 110 revisi 2015," ungkap Noor.

Ada perjanjian wali amanat sukuk yang perlu memuat jenis akad. Selain itu, perlu disampaikan juga tujuan penggunaan dana sukuk, ada aset yang mendasar (underlying asset) dan kewajiban wali amanat, rapat umum pemegang sukuk, serta mekanisme pembayaran hasil sukuk. Juga pernyataan jaminan semua pendapatan bebas dari yang tidak halal dan sesuai prinsip syariah.

"Karena sama seperti korporasi, sukuk daerah harus didaftarkan ke OJK. Setelah itu baru bisa dilakukan bookbuilding untuk menentukan harga sukuk dan menentukan nisbah," tegas Noor. OJK bisa memberikan pernyataan efektif dan sertifikasi sukuk bisa didistribusikan kepada para 
investor. Kemudian, penerbit tetap harus memberikan keterbukaan yang berkaitan harga sukuk terbitannya. Dikutip dari artikel keuangansyariah.mysharing.com (2015).

Sebuah artikel yang ditulis Muhammad Shodiq (2008) menyebutkan ada beberapa permasalahan yang dihadapi daerah dalam penerbitan sukuk, antara lain pertama, belum lengkapnya payung hukum seperti belum adanya Undang-Undang Pasar Modal tentang penerbitan sukuk daerah dan juga Undang-Undang SBSN tentang sukuk daerah. Kedua, kesiapan SDM dalam mengelola sukuk sesuai dengan standar pasar modal. Karena belum meluasnya pemahaman aparat daerah terkait ketentuan pasar modal sukuk daerah maupun terkait dengan konsep dan skema syariah. Ketiga, tidak adanya jaminan pemerintah pusat dalam menerbitkan sukuk daerah sehingga investor menganggap sukuk daerah berisiko tinggi, kepala daerah harus terlebih dulu mendapat persetujuan dari DPRD dan pemerintah pusat dan keempat, lokasi investor hanya domestik dan hanya dalam denominasi rupiah.

Berdasarkan hasil wawancara yang dilakukan penulis terhadap Bapak Irfan Syauqi Beik terdapat 3 poin yang membuat daerah belum menerbitkan sukuk yaitu :

Regulasi dari pemerintah : UU SBSN belum membuka ruang secara eksplisit untuk pengembangan sukuk daerah karena SBSN itu diterbitkan oleh pemerintah, SPV perusahaan penerbit SBSN harus jelas ataukah terkait dengan pusat, aspek-aspek tujuan pengeluaran sukuk, proporsi utang daerah yang mengeluarkan sukuk maksimal $3 \%$ dari PDB karena sukuk menimbulkan utang tergantung akad sehingga harus di kalkulasi dengan PDB, UU tentang pemerintah daerah dan regulasi tentang kriteria daerah yang menerbitkan sukuk

Kesiapan daerah: infrastruktur daerah (infrastruktur kelembagaan), perda daerah (untuk memberikan payung hukum) sehingga sukuk tidak bisa dikeluarkan hanya karena perintah gubernur, kesiapan SDM, kesiapan birokrasi, apakah sukuk diterbitkan oleh propinsi ataukah kota karena sekarang otonomi di kota sehingga jika dikeluarkan propinsi harus ada pola hubungan antara propinsi dengan kabupaten kota (pembebanan APBDnya dimasukkan ke propinsi ataukah kota, atau APBD di share antara propinsi dan kota), siapa SPVnya haruskah membuat perusahaan khusus penerbit sukuk daerah dan bagaimana peraturannya, kondisi keuangan daerah (jangan sampai rasio beban lebih besar)

Perencanaan pembangunan : apakah sukuk sudah masuk dalam perencanaan pembangunan daerah tentang projek apa yang harus dibiayai, apakah daerah siap mengeluarkan untuk fee sukuk (menggunakan akad ijaroh $(90 \%$ menggunakan sukuk ijaroh) atau wakalah)

Dari masalah yang tersebut diatas, penulis membaginya menjadi dua yaitu masalah internal dan masalah eksternal. Sehingga didapatkan skema seperti gambar 1.

\section{Prioritas Utama Masalah}

Berdasarkan metodologi yang digunakan yaitu ANP untuk melihat skala prioritas menurut kalangan pakar dan praktisi keuangan syariah terutama sukuk maka hasilnya dapat dilihat dari uraian berikut :

\section{Analisis Masalah}

Masalah belum diterapkannya municipal islamic bonds pada daerah yang berpotensi untuk menerbitkan sukuk di Indonesia, dapat dibagi menjadi dua masalah utama, yaitu masalah internal $(0,74)$ dan masalah eksternal $(0,26)$. Para pakar dan praktisi yang menjadi responden peneliti sependapat bahwa masalah utama terdapat pada kedua aspek tersebut.

Hal ini menunjukkan bahwa faktor belum diterapkannya municipal islamic bonds pada daerah yang berpotensi sukuk di Indonesia tidak hanya berasal dari faktor internal daerah itu sendiri tetapi juga ada peran dari pihak luar seperti halnya pemerintah, para 


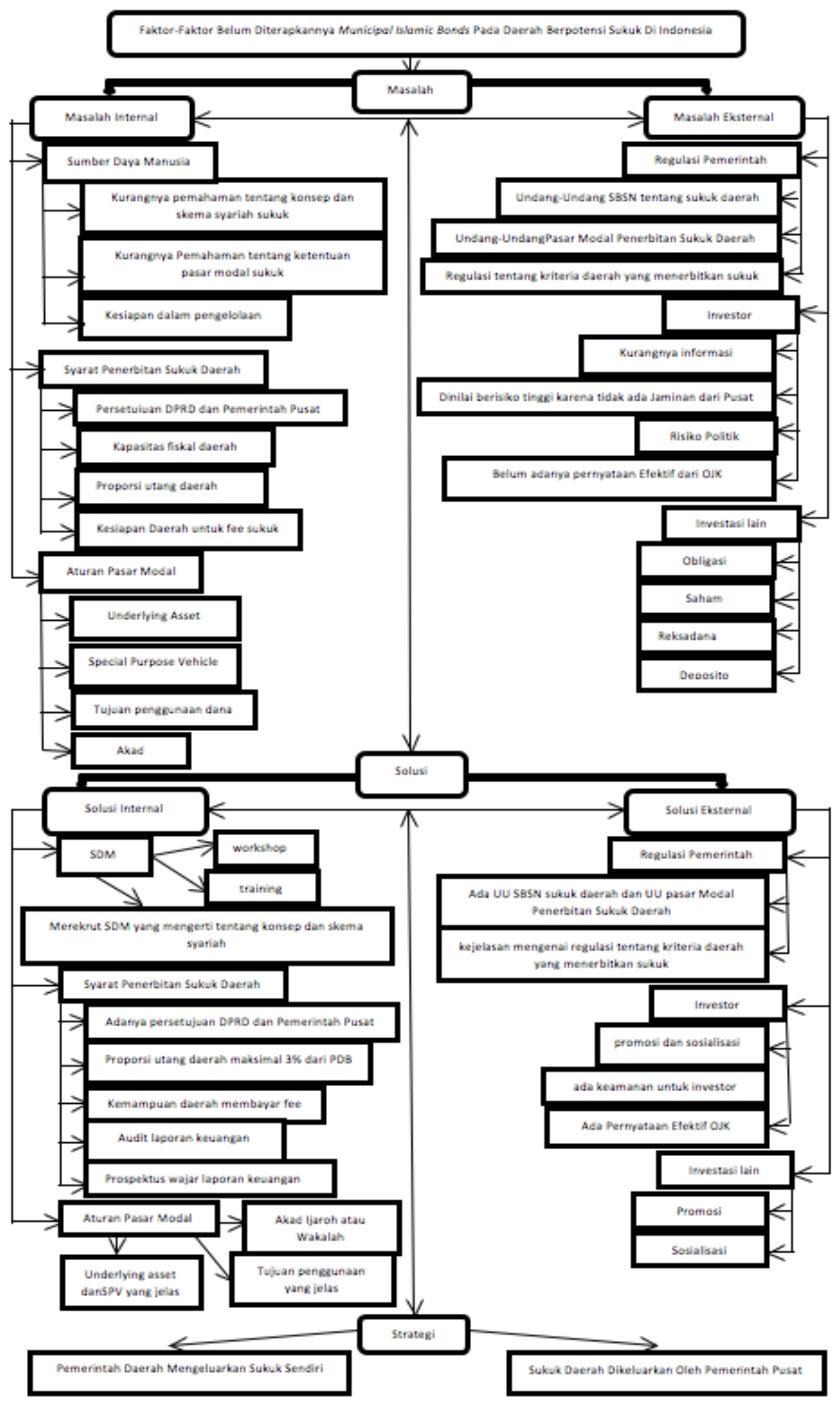

Gambar 1: Kerangka ANP belum diterapkannya municipal islamic bonds 


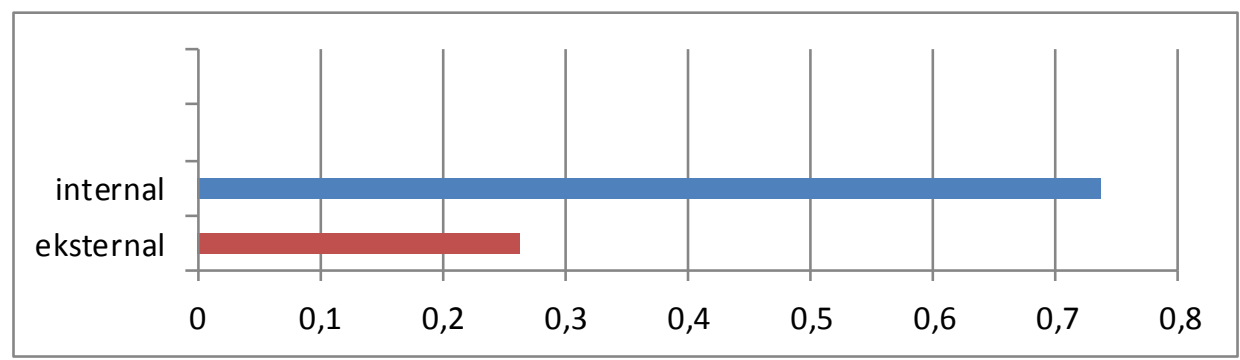

Gambar 2: Masalah Belum Diterapkannya Municipal Islamic Bonds pada daerah berpotensi sukuk di Indonesia

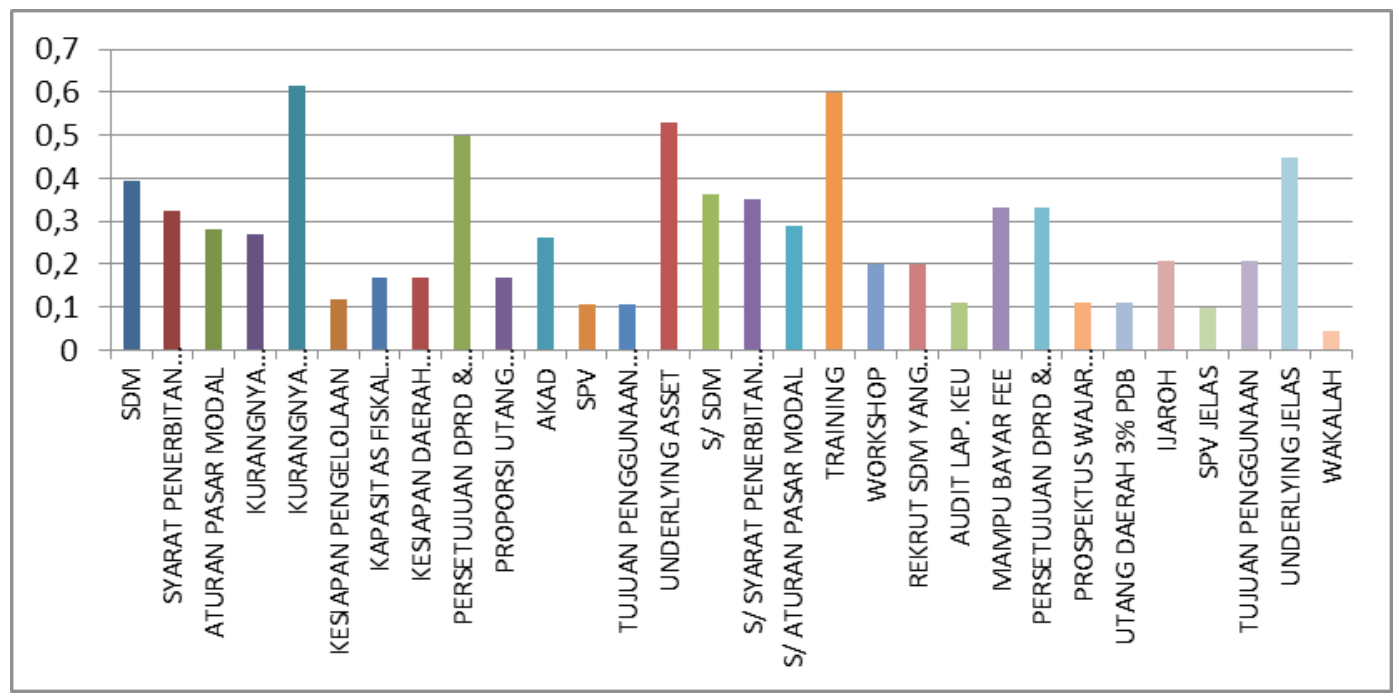

\section{Gambar 3 : Rincian Masalah Internal dan Solusi Internal}

investor dan juga adanya investasi lain yang bisa menjadi kompetitor. Maka perlu adanya hubungan positif yang saling mendukung antara kedua aspek (internal dan eksternal) sehingga pemerintah daerah yang memiliki potensi untuk mengeluarkan sukuk dapat menerbitkan sukuk guna membiayai infrastruktur daerah serta dapat juga digunakan untuk menutupi defisit APBD.

\section{Analisis Masalah Internal dan Solusi Internal}

Pada masalah internal yang menjadi masalah utama adalah sumber daya manusia (0.39). Sudah seharusnya jika pemerintah daerah ingin menerbitkan sukuk harus di dukung dengan SDM yang memadai dan memiliki pengetahuan yang cukup tentang sukuk sehingga mampu mengelola sukuk daerah sesuai dengan syariah islam dan mampu memberikan kemajuan bagi daerah.

Permasalahan kedua ada pada syarat penerbitan sukuk daerah (0.32). Daerah yang berpotensi sukuk pasti harus memenuhi syarat yang berhubungan dengan kesiapan pembayaran fee sukuk serta proporsi utang sudah sesuai syarat dan ketentuan dari pemerintah. Terakhir adalah masalah aturan pasar modal (0.28).

Berdasarkan masalah yang ada solusi yang lebih diprioritaskan untuk dibenahi adalah internal daerah yaitu SDM (0.36) sedang prioritas kedua adalah solusi syarat penerbitan sukuk daerah (0.35) dan yang terakhir adalah solusi tentang aturan pasar modal (0.29).

Dilihat dari gambar, dapat terlihat bahwa masalah utama dalam SDM adalah kurangnya pemahaman tentang ketentuan pasar modal sukuk (0.61). Saat menerbitkan 
sukuk dipasar modal harus tahu aturan penerbitannya jika pemahaman tentang hal ini kurang maka akan memjadi kendala terbesar. Kedua, kurangnya pemahaman tentang konsep dan skema syariah sukuk (0.27). Keuangan syariah di Indonesia memang sedang dalam masa pertumbuhan sehingga masih memiliki sedikit ahli keuangan syariah terutama sukuk. Apalagi para pegawai pemerintah daerah, tidak banyak yang memiliki dasar pemahaman tentang keuangan syariah. Wajar jika kurangnya pemahaman tentang konsep dan skema syariah sukuk menjadi urutan kedua dalam hal masalah SDM. Terakhir, kesiapan SDM daerah dalam pengelolaan sukuk (0.12). Jika poin satu dan dua dalam masalah SDM bisa teratasi maka tidak sulit bagi pemerintah daerah untuk mengelola sukuk.

Solusi bagi masalah SDM adalah training (0.6) jika SDM belum terlalu mengenal tentang sukuk maka solusi yang paling efektif adalah melakukan training kepada para pegawai pemerintah daerah yang berhubungan dengan penerbitan sukuk serta pengelolaannya. Serta melakukan workshop (0.2) dan merekrut SDM yang mengerti tetang konsep skema syariah sukuk serta aturan pasar modal (0.2). Merekrut SDM menjadi solusi terakhir karena dirasa kurang efektif jika harus merekrut orang baru dalam pemerintahan daerah sebab jika melakukan perekrutan akan memerlukan biaya dan memerlukan waktu. Padahal tugas dari pemerintah daerah tidak hanya mengenai sukuk saja tetapi ada hal lain yang harus dikerjakan.

Sedangkan masalah utama dalam syarat penerbitan Municipal Islamic Bonds adalah persetujuan DPRD dan pemerintah pusat yang memiliki proporsi 0.5. Sedangkan masalah lainnya seperti kapasitas fiskal daerah, proporsi utang daerah dan kesiapan daerah untuk fee sukuk yang masing-masing memiliki proporsi yang sama yaitu 0.17. Memang kalau pemerintah memberikan dukungan serta persetujuan kepada daerah untuk mengeluarkan sukuk maka akan mempermudah dalam pelaksanaannya. Sehingga persetujuan DPRD dan pemerintah pusat menjadi faktor masalah yang memiliki porsi paling besar.

Solusi dari masalah syarat penerbitan sukuk daerah adalah adanya persetujuan DPRD dan pemerintah pusat (0.33), serta daerah yang mengeluarkan sukuk memang mampu membayar fee kepada investor (0.33). Daerah penerbit sukuk juga harus memiliki proporsi utang daerah maksimal 3\% dari PDB (0.11). Laporan keuangan daerah juga perlu dilakukan pengauditan (0.11) dan prospektus laporan keuangan juga harus mendapat opini wajar dilihat dari laporan keuangan tahun sebelumnya (0.11).

Masalah aturan pasar modal yang menjadi faktor utama adalah Underlying Asset (0.53) kedua masalah akad (0.26), serta SPV dan tujuan penggunaan sukuk menjadi urutan terakhir (0.11). Saat menerbitkan sukuk memang harus memiliki asset yang dijadikan sebagai dasar untuk menerbitkan sukuk. Tanpa Undelying Asset tentu pemerintah daerah tidak dapat mengeluarkan sukuk. Tidak seperti obligasi yang tidak memerlukan unerlying asset. Mungkin inilah penyebab kenapa Undelying Asset bisa memiliki proporsi paling tinggi. Masalah kedua ada pada akad, banyak akad yang bisa digunakan dalam penerbitan sukuk, tetapi daerah harus tahu mana akad yang cocok diterapkan di daerahnya dan juga akad apa yang diminati investor serta akad yang mampu untuk dikelola oleh SDM daerah.

Masalah aturan pasar modal dapat diatasi dengan pemerintah memiliki undelying asset yang jelas (0.45) sebagai dasar penerbitan sukuk. Kedua, memiliki tujuan yang jelas, dana hasil penerbitan sukuk harus jelas pemanfaatannya (0.21). Akad yang lebih memungkinkan untuk dapat diterapkan di Indonesia adalah akad ijaroh (0.2), dalam penerbitan sukuk tentu membutuhkan yang namanya SPV (0.1) terakhir akad wakalah (0.04) yang memiliki skala paling kecil. 


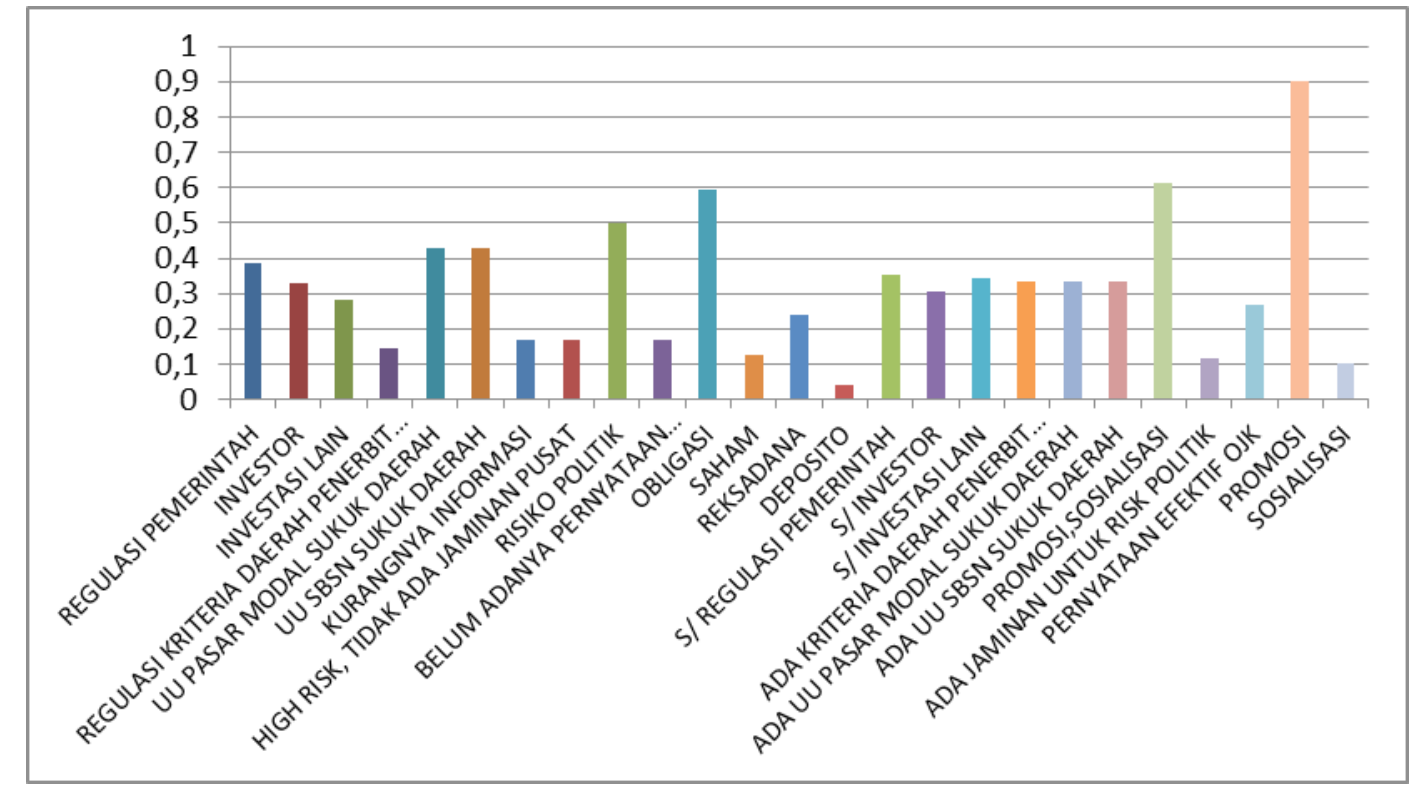

Gambar 4 : Rincian Masalah Eksternal dan Solusi Eksternal

\section{Analisis Masalah Eksternal dan Solusi Eksternal}

Masalah utama pada masalah eksternal ada pada regulasi pemerintah (0.39). Masalah kedua ada pada investor (0.33). Sedang investasi lain merupakan urutan terakhir (0.28). Jika sukuk daerah tidak memiliki payung hukum yang kuat, pasti akan menyulitkan pemerintah daerah untuk menerbitkan sukuk. Sehingga masalah regulasi pemerintah bisa menjadi prioritas utama dalam masalah eksternal. Informasi tentang sukuk daerah yang belum menyebar luas keseluruh kalangan masyarakat serta adanya risiko yang timbul dari investasi sukuk seperti risiko politik serta investor mengira sukuk memiliki risiko yang tinggi dan belun adanya pernyataan secara resmi dari OJK tentang keefektifan sukuk daerah menjadikan masalah investor menduduki prioritas kedua. Investasi lain menduduki urutan terakhir karena setiap investasi memiliki karakteristik dan ciri khas yang berbeda-beda sehingga keputusan investasi tergantung dari sudut pandang investor. Apakah investor sebagai orang yang suka dengan risiko tinggi dan menghasilkan banyak keuntungan, atau investor sebagai tipe orang yang suka bermain aman yaitu sedikit risiko, ataukah yang suka berspekulasi tanpa memikirkan untung atau rugi.

Dari masalah eksternal yang ada, solusi yang lebih diprioritaskan adalah solusi tentang regulasi pemerintah (0.35), solusi investasi lain (0.34) dan terakhir solusi investor (0.31). Tidak bisa dipungkiri bahwa masalah yang berhubungan dengan hukum adalah masalah yang paling krusial sehingga solusi regulasi pemerintah menjadi prioritas utama.

Pada masalah regulasi pemerintah, masalah utama ada pada UU SBSN sukuk daerah dan UU pasar modal tentang penerbitan sukuk daerah dengan nilai prioritas 0.43 , masalah berikutnya adalah regulasi tentang kriteria daerah yang menerbitkan sukuk (0.14). Undang-Undang yang dapat mendukung daerah menerbitkan sukuk memang sangat penting karena jika tidak memiliki UU sebagai dasar hukum maka kedudukan sukuk daerah menjadi lemah. Sehingga regulasi tentang kriteria daerah yang menerbitkan sukuk menjadi 
prioritas masalah terakhir dalam regulasi pemerintah setelah UU.

Berdasarkan masalah regulasi pemerintah, dari ketiga elemen solusi yang ditawarkan memiliki nilai prioritas yang sama yaitu 0.33 . Tiga elemen itu adalah adanya UU SBSN tentang sukuk daerah, adanya UU pasar modal tentang penerbitan sukuk daerah serta adanya kejelasan mengenai regulasi tentang kriteria daerah yang menerbitkan sukuk. Masalah regulasi pemerintah memang memiliki pengaruh yang sangat kuat dan ada keterkaitan antara satu dengan yang lainnya itulah yang menyebabkan nilai prioritas dari ketiga solusi elemen tersebut bernilai sama.

Dalam masalah Investor, risiko poitik menjadi masalah utama (0.5) karena terjadi ketakutan dari para investor apabila terjadi pergantian jabatan dalam pemerintahan akan menyebabkan terjadinya kebijakan baru yang bisa berimbas pada sukuk daerah yang telah diterbitkan. Investor takut kalau sukuk tidak diakui karena investor ingin kepastian. Masalah investor berikutnya adalah kurangnya informasi investor tentang sukuk daerah, sukuk daerah dinilai investor memiliki risiko yang tinggi karena tidak memiliki jaminan dari pusat dan OJK belum memberikan pernyataan resmi tentang keefektifan sukuk daerah. Ketiga elemen tersebut memiliki niali prioritas yang sama yaitu 0.17 .
Solusi dari masalah investor yang paling utama adalah melakukan promosi dan sosialisasi (0.61) karena masih banyak masyarakat yang belum begitu mengenal sukuk maka perlu promosi serta sosialisasi supaya lebih bisa menarik investor untuk berinvestasi di sukuk. Solusi kedua adalah adanya pernyataan efektif dari OJK tentang sukuk daerah (0.27), solusi terakhir adalah ada jaminan untuk investor tentang risiko politik (0.12).

Kompetitor utama dari sukuk daerah adalah obligasi (0.6) yang sudah familiar dikalangan masyarakat dan memiliki karakteristik yang hampir sama dengan sukuk, masalah kedua reksadana (0.24) lalu Saham (0.13) yang mudah dijual-belikan dipasar sekunder yang memudahkan investor untuk memindah tangankan saham setiap saat, investor yang suka spekulasi akan lebih memilih saham dan yang terakhir adalah deposito (0.04).

Solusi utama untuk masalah investasi lain adalah melakukan promosi (0.9), Solusi kedua adalah melakukan sosialisasi (0.1). Jika pemerintah sudah resmi menerbitkan sukuk daerah maka solusi yang paling efektif agar bisa menarik investor supaya berpindah untuk berinvestasi di sukuk adalah dengan gencar melakukan promosi, tidak hanya menyampaikan kelebihan yang diperoleh jika berinvestasi di sukuk dan menginformasikan perbedaan sukuk

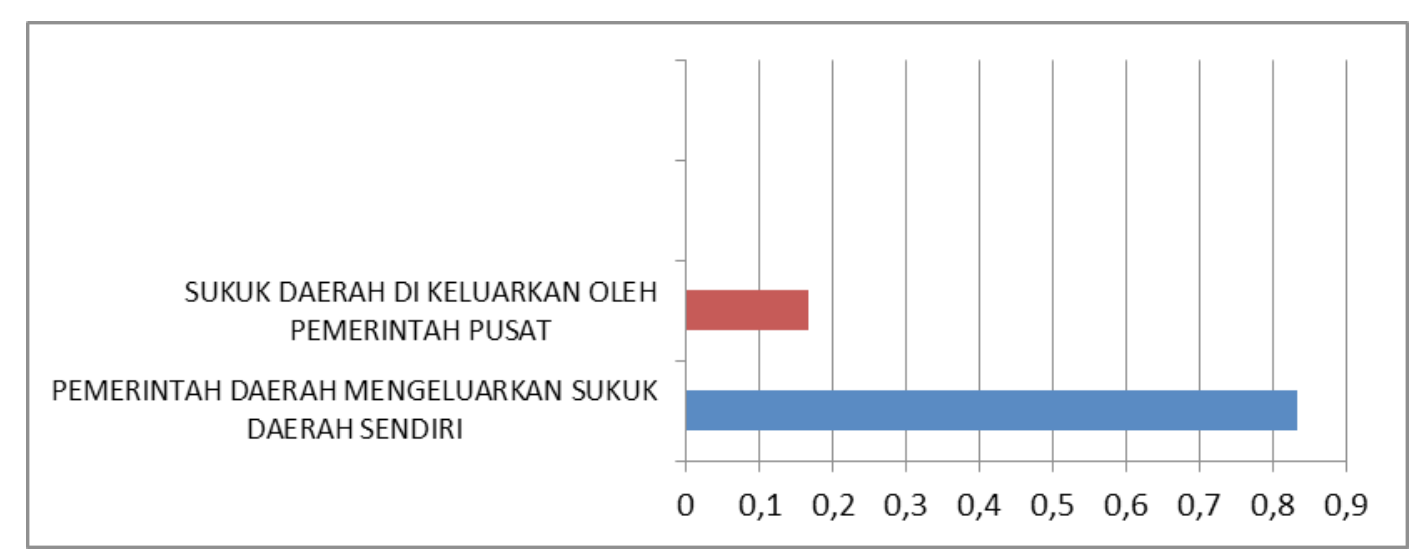

Gambar 4.6 : Rincian Strategi Masalah Belum Diterapkannaya Municipal Islamic Bonds pada Daerah Berpotensi Sukuk di Indonesia 
dengan investasi lain. Promosi lebih tepat jika dilakukan kepada kalangan menengah keatas yang sadar tentang pentingnya berinvestasi secara syariah.

\section{Analisis Strategi}

Berdasarkan kompleksitas masalah yang sudah diuraikan diatas, strategi yang lebih di prioritaskan untuk dapat menerbitkan municipal islamic bonds adalah pemerintah daerah mengeluarkan municipal islamic bonds sendiri (0.83). Jika daerah mengeluarkan sukuk sendiri maka akan memudahkan daerah untuk mengelolanya karena daerah yang paling tahu keadaan daerahnya dan apa saja yang dibutuhkan oleh daerah.

Sedangkan strategi aplikatif selanjutnya adalah municipal islamic bonds dikeluarkan oleh pemerintah pusat (0.17). Jika memang daerah belum bisa mengeluarkan sukuk sendiri, terpaksa daerah masih mengekor

Tabel 2: Ringkasan Hasil Analisa Faktor Belum Diterapkannya Municipal Islamic Bonds pada Daerah Berpotensi Sukuk di Indonesia

\begin{tabular}{|c|c|c|c|}
\hline \multirow{2}{*}{ Aspek } & \multicolumn{3}{|c|}{ RANKING } \\
\hline & 1 & 2 & 3 \\
\hline $\begin{array}{l}\text { Masalah } \\
\text { internal }\end{array}$ & $\begin{array}{l}\text { SDM : kurangnya } \\
\text { pemahaman tentang } \\
\text { aturan pasar modal } \\
\text { sukuk, kurangnya } \\
\text { pemahaman tentang } \\
\text { konsep dan skema } \\
\text { syariah sukuk dan } \\
\text { kesiapan pengelolaan } \\
\text { sukuk. }\end{array}$ & $\begin{array}{l}\text { Syarat penerbitan } \\
\text { municipal islamic bonds } \\
\text { : persetujuan DPRD } \\
\text { dan pemerintah pusat, } \\
\text { kapasitas fiskal daerah, } \\
\text { proporsi utang daerah dan } \\
\text { kesiapan fee sukuk. }\end{array}$ & $\begin{array}{l}\text { Aturan Pasar Modal } \\
\text { : Underlying Asset, } \\
\text { akad, SPV, dan tujuan } \\
\text { penggunaan sukuk. }\end{array}$ \\
\hline $\begin{array}{l}\text { Solusi } \\
\text { internal }\end{array}$ & $\begin{array}{l}\text { Solusi SDM : training, } \\
\text { workshop, dan rekrut } \\
\text { SDM yang mengerti } \\
\text { konsep da skema syariah } \\
\text { sukuk. }\end{array}$ & $\begin{array}{l}\text { Solusi Syarat penerbitan } \\
\text { municipal islamic bonds } \\
\text { : adanya persetujuan } \\
\text { DPRD dan pemerintah } \\
\text { pusat, kemampuan daerah } \\
\text { membayar fee, dan } \\
\text { proporsi utang max } 3 \% \text {. }\end{array}$ & $\begin{array}{l}\text { Solusi aturan pasar modal } \\
\text { : memiliki underlying asset, } \\
\text { tujuan penggunaan dana } \\
\text { yang jelas, akad ijaroh, } \\
\text { SPV dan akad wakalah. }\end{array}$ \\
\hline $\begin{array}{l}\text { Masalah } \\
\text { eksternal }\end{array}$ & $\begin{array}{l}\text { Regulasi Pemerintah : } \\
\text { UU pasar modal dan UU } \\
\text { SBSN municipal islamic } \\
\text { bonds, dan kriteria } \\
\text { daerah yang menerbitkan } \\
\text { sukuk. }\end{array}$ & $\begin{array}{l}\text { Investor : Risiko Politik, } \\
\text { kurangnya informasi, } \\
\text { belum adanya pernyataan } \\
\text { efektif OJK, dan High risk } \\
\text { karena tidak ada jaminan } \\
\text { dari pusat }\end{array}$ & $\begin{array}{l}\text { Investasi lain : obligasi, } \\
\text { reksadana, saham dan } \\
\text { deposito }\end{array}$ \\
\hline $\begin{array}{l}\text { Solusi } \\
\text { eksternal }\end{array}$ & $\begin{array}{l}\text { Solusi Regulasi } \\
\text { Pemerintah : adanya UU } \\
\text { pasar modal, UU SBSN } \\
\text { municipal islamic bonds } \\
\text { dan adanya kejelasan } \\
\text { tentang kriteria daerah } \\
\text { penerbit sukuk. }\end{array}$ & $\begin{array}{l}\text { Solusi Investasi lain : } \\
\text { Promosi dan sosialisasi }\end{array}$ & $\begin{array}{l}\text { Solusi investor : promosi } \\
\text { dan sosialisasi, adanya } \\
\text { pernyataan efektif dari } \\
\text { OJK dan jaminan investor } \\
\text { tentang risiko politik. }\end{array}$ \\
\hline Strategi & $\begin{array}{l}\text { Pemerintah daerah } \\
\text { mengeluarkan sukuk } \\
\text { sendiri }\end{array}$ & $\begin{array}{l}\text { Municipal Islamic } \\
\text { Bonds dikeluarkan oleh } \\
\text { pemerintah pusat }\end{array}$ & \\
\hline
\end{tabular}

Sumber: Data primer yang diolah melalui ANP 
pusat dalam penerbitannya.

Berdasarkan uraian diatas, dapat disimpulkan dalam tabel 2 .

\section{SIMPULAN}

Berdasarkan pembahasan dan analisa faktor belum diterapkannya municipal islamic bonds pada daerah berpotensi sukuk di Indonesia, berikut dapat ditarik beberapa kesimpulan mengenai pembahasan ini, diantaranya adalah

Masalah belum diterapkannya municipal islamic bonds pada daerah yang berpotensi sukuk di Indonesia dapat dikerucutkan menjadi dua masalah pokok yaitu masalah internal dan masalah eksternal.

Aspek internal terbagi lagi menjadi dua masalah utama yaitu masalah SDM (kurangnya pemahaman tentang aturan pasar modal sukuk, kurangnya pemahaman tentang konsep dan skema syariah sukuk) dan syarat penerbitan municipal islamic bonds (persetujuan DPRD dan pemerintah pusat). Masalah eksternal juga terbagi menjadi dua yaitu Regulasi Pemerintah (UU pasar modal dan UU SBSN municipal islamic bonds) dan Investor (Risiko Politik)

Berdasarkan masalah yang ada, maka solusi yang lebih diprioritaskan berdasarkan aspek internal meliputi SDM (training, workshop) dan Syarat penerbitan municipal islamic bonds (adanya persetujuan DPRD dan pemerintah pusat, kemampuan daerah membayar fee) sedangkan solusi yang berkenaan dengan aspek eksternal meliputi solusi Regulasi Pemerintah (adanya UU pasar modal dan UU SBSN municipal islamic bonds) dan solusi Investasi lain (Promosi).

Strategi yang dapat dilakukan untuk mewujudkan municipal islamic bonds adalah Pemerintah daerah mengeluarkan sukuk sendiri.

Masalah belum diterapkannya municipal islamic bonds pada daerah yang berpotensi sukuk di Indonesia merupakan masalah yang melibatkan berbagai pihak. Salah satunya adalah SDM dari pemerintahan daerah itu sendiri sehingga jika memang daerah ingin menerbitkan sukuk maka harus mempersiapkannya dengan matang. Training bagi pegawai yang bersangkutan sangat perlu dilakukan.

Pemerintah harus mendukung keinginan pemerintah daerah untuk menerbitkan municipal islamic bonds. Pemerintah perlu membuat kebijakan dengan mengeluarkan UU yang bisa menjadi landasan hukum penerbitan municipal islamic bonds.

Daerah memerlukan alternatif pembiayaan karena keterbatasan anggaran daerah. Salah satu alternatif yang bisa ditempuh pemerintah adalah dengan menerbitkan sukuk. Penerbitan sukuk bisa membantu daerah dalam mewujudkan RPJMD (Rencana Pembangunan Jangka Menengah Daerah) dan RPJMN (Rencana Pembangunan Jangka Menengah Nasional)

Jika daerah ingin menerbitkan sukuk, perlu melakukan promosi serta sosialisasi karena kurangnya pemahaman tentang sukuk baik dari kalangan pemangku di pemerintahan, investor serta masyarakat umum.

\section{DAFTAR PUSTAKA}

Accounting And Organization For Islamic Institution. (2008). Shari'a Standard For Islamic Financial Institution Standard 17

Direktorat Pembiayaan Syariah, DJPPR, Kementerian Keuangan. (2015). Sukuk Negara Instrumen Keuangan Berbasis Syariah. Jakarta : Asian Development Bank

Faisal, Heri. (2016). OJK Dorong Pemda Terbitkan Obligasi Daerah. http://market.bisnis.com/ read/20160414/92/538044/ojk-dorong-pemda-terbitkan-obligasi-daerah

Fatwa DSN MUI Nomor: 32/DSN-MUI/IX/2002 tentang Obligasi Syariah 
Firmansyah, Deki. (2016). Potensi Pemanfaatan Sukuk Daerah Dalam Percepatan Pembangunan Daerah (Studi Kasus Pada Pemerintah Daerah Provinsi Sumatera Selatan). Skripsi Manajemen Keuangan. Fakultas Ekonomi Universitas Sriwijaya

Hamzah, M. Maulana. (2015). Prospek pengembangan green municipal islamic bonds pada daerah berpotensi sukuk di indonesia. Paper forum riset ekonomi dan keuangan syariah IV Terpilih

Huda, N. et al. (2012). Keuangan Publik Islami: Pendekatan teoritis dan sejarah. Jakarta: Kencana Prenada media group.

Muslim, Sarip. (2010). Prospek Pengembangan Obligasi Daerah Dengan Instrumen Sukuk Oleh Pemerintah Kabupaten/Kota Di Provinsi Jawa Barat. Thesis / disertasi Universitas Gadjah Mada.

Natadipurba, Chandra. (2015). Ekonomi Islam 101. Bandung : PT Mobidelta Indonesia

Peraturan Pemerintah Republik Indonesia Nomor 30 Tahun 2011 Tentang Pinjaman Daerah

Shodiq, Muhammad. Urgensi Sukuk bagi pemerintah daerah Kandidat CIFP di International Centre for Education in Islamic Finance, Malaysia. (madani-ri.com)

Tanjung, Hendri dan Devi, Abrista. (2013). Metodologi Penelitian Ekonomi Islam. Jakarta : Gramata Publishing

Undang-undang Republik Indonesia Nomor 19, Tahun 2008 tentang SBSN

Walidi. (2009). Peta Penawaran dan Permintaan Sukuk Daerah. Thesis Pasca Sarjana Kajian Timur Tengah dan Islam Universitas Indonesia

www.fiskal.kemenkeu.go.id. Diakses Februari 2016

Yusuf, A. (2014). Prospek Sukuk Sebagai Alat Pembiayaan Defisit Apbn. www.acamedia. edu/7618996/prospek Sukuk sebagai alat pembiayaan defisit apbn Diakses pada

Februari 2016 